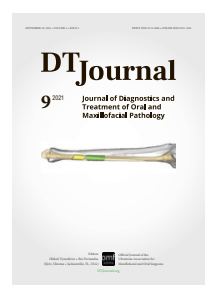

SECTION BUSINESS: EDITORIAL

Ivan V. Nagorniak, MSc, PhD, Section Editor

\title{
Ukraine: Legal Forms for Private Practice in Oral Surgery and Dentistry
}

\author{
Nataliia M. Koba \& Ivan V. Nagorniak, ${ }^{b}$ *
}

\begin{abstract}
During thelast 30 years of Ukrainian independence the private dental businesses are flourishing what is a very good sign not only for patients and dental professionals, but also for economy. As of January 1, 2019, 4,584 privately owned dental institutions were registered Ukraine. Among them, 669 were dental clinics and 3,915 - dental offices. ${ }^{1}$ Generally, dental care in Ukraine (as of January 1, 2019) was provided by 25,651 dentists of six specialties. ${ }^{1}$ According to these 2019 data, we can hypostatize that every sixth dentist in Ukraine is an owner of a private clinic/office. ${ }^{1}$ Moreover, as of January 1, 2021, the number of private dental practices for the first time in history of this country increased to 5,084 (ie, showed a 8.72 percent growth during a 2019 to 2021 period). ${ }^{2}$

The clear understanding of the corporate law for private practice activity is an important element to start an own business. There are three common types of legal forms registered by the clinic/office owners: Individual Entrepreneur (transliteration from Ukrainian, fizychna osoba-pidpryiemets
\end{abstract}

Kyiv, Ukraine

${ }^{a}$ MSc, Former Head Doctor, Limited Liability Company Scientific Center of Dentistry and Ultrasound Surgery.

${ }^{\mathrm{b}} \mathrm{MSc}, \mathrm{PhD}$, Head Doctor, Private Entrepreneur Nagorniak I.V.

* Corresponding author's address: Private Practice (Certificate for management system according to ISO 9001:2015 - Private Entrepreneur Nagorniak I.V.), 6-G Andruschenka Street, Office 6, Kyiv 01135, Ukraine. E-mail: ivan.nagorniak@gmail.com (Ivan Nagorniak)
[FOP]) (other names: Private Entrepreneur, Sole Proprietor, Physical Person-Entrepreneur), ${ }^{3}$ Private Enterprise (transliteration from Ukrainian, pryvatne pidpryiemstvo $[\mathrm{PP}]),{ }^{4}$ and Limited Liability Company (transliteration from Ukrainian, tovarystvo $z$ obmezhenoiu vidpovidalnistiu [TOV]). ${ }^{5}$ The first legal form is individual, second and third are legal entities. Also, the founder of the dental business must know, that despite Individual Entrepreneur has multiple advantages, it is not a legal entity so it cannot be divided into shares and to belong to different shareholders. ${ }^{6}$

Interestingly, that among legal forms in private dentistry established in 1990s there can be found such type of business as Multiprofile Small Private Enterprise (transliteration from Ukrainian, bahatoprofilne male pryvatne pidpryiemstvo [BP $\mathrm{MPP}]) .^{3}$

Upon state registration a core thing is to indicate the Dental Practice (ie, Stomatological Practice) as the main activity regardless of what legal form the founder chooses. ${ }^{7}$ Dental practice class according to 
2010 Classification of types of economic activities

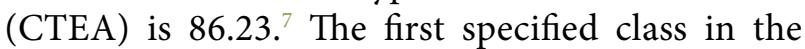
registration application (according to CTEA), will be considered as the main activity. It is important to know that Ukrainian legislation is not limiting the number of economic activities which can be performed by one legal form.

Before choosing one of the legal forms for the future dental clinic/office, the dentist should answer the next questions:

1. Does he/she want to have other dentists/ persons as the co-founders (ie, business partners)? For example, the number of cofounders in the dental practice which is registered as Limited Liability Company from June 17, 2018 is unlimited (Law of Ukraine "On Limited and Additional Liability Companies" \#2275-VIII). ${ }^{8}$ In contrast, a business founded as Individual Entrepreneur legal form cannot be re-registered with another investor/co-founder or acquired by him.

2. Does he/she plan in future to raise additional money from possible new co-founders/ shareholders?

3. Which tax system he/she plan to choose?

4. How many employees are planned in addition to the future dentist as a practice owner?

5. Degree of responsibility for property. Does the founding dentist agree to be liable for his own obligations with his own property?

After answering those questions and consultation with a lawyer, or other person who had such experience, it's possible to move to the next steps in realization of the dream.

\section{REFERENCES (8)}

1. Mazur IP, Pavlenko OV, Srypnyk IL. Ukrainian scientific dental school: historical essays (in Ukrainian). Kropyvnytskyi, Ukraine: Polium; 2020.

2. State institution "Center for Medical Statistics of the Ministry of Health of Ukraine" (in Ukrainian) [document on the internet]; Aug 25, 2021 [cited 2021 Aug 25]. Available from:

http://medstat.gov.ua/ukr/main.html

3. FOP Kosteichuk O.M. [document on the internet]; Aug 26, 2021 [cited 2021 Aug 27]. Available from: https://youcontrol.com.ua/en/catalog/fop_ details/33902666/

4. BP MPP UNIVERSAL-96 [document on the internet]; Aug 26, 2021 [cited 2021 Aug 27]. Available from:

https://youcontrol.com.ua/en/catalog/company_ details/24879118/

5. TZOV MM [document on the internet]; Aug 26, 2021 [cited 2021 Aug 27]. Available from:

https://youcontrol.com.ua/catalog/company_ details/13795633/

6. We register the business: IE against LLC (in Ukrainian) [document on the internet]; Aug 28, 2021 [cited 2021 Aug 28]. Available from:

https://uteka.ua/ua/publication/news-14-delovyenovosti-36-registriruem-svoj-biznes-flp-protiv-ooo

7. CTEA-2010: class 86.23 (in Ukrainian) [document on the internet]; Aug 28, 2021 [cited 2021 Aug 28]. Available from:

http://kved.ukrstat.gov.ua/KVED2010/86/ KVED10_86_23.html

8. Law of Ukraine: about limited and additional liability companies (in Ukrainian) [document on the internet]; Aug 28, 2021 [cited 2021 Aug 28]. Available from:

https://zakon.rada.gov.ua/laws/show/2275-19\#Text 